See discussions, stats, and author profiles for this publication at: https://www.researchgate.net/publication/326928691

\title{
Permainan Estafet Lagu: Model Pemusatan Perhatian sesuai Karakter dan Gaya belajar Anak Usia Dini
}

Book · January 2017

CITATIONS

0

1 author:

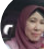

Situs Resmi Universitas Negeri Padang

7 PUBLICATIONS 0 CITATIONS

SEE PROFILE

Some of the authors of this publication are also working on these related projects:

MODEL PERMAINAN ESTAFET BAIT LAGU UNTUK MENINGKATKAN KEMAMPUAN PEMUSATAN PERHATIAN PADA ANAK View Project
READS

26

All content following this page was uploaded by Ismaniar Ismaniar on 10 August 2018. 


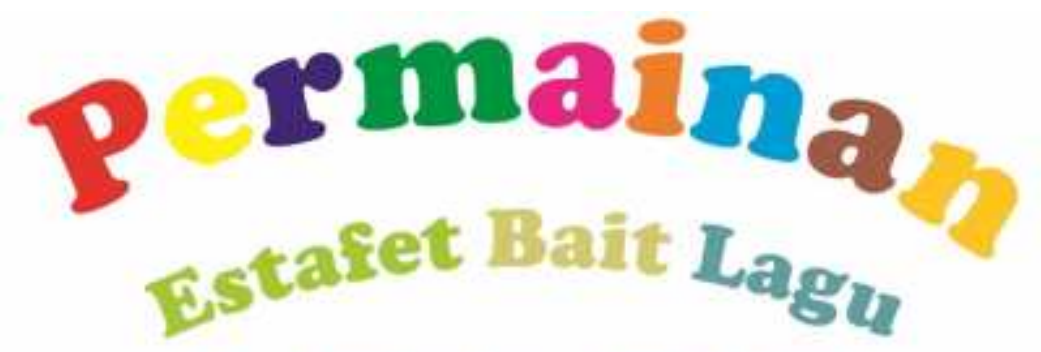

Model Pemusatan Perhatian sesuai Karakter dan Gaya Belajar Anak Usia Dini

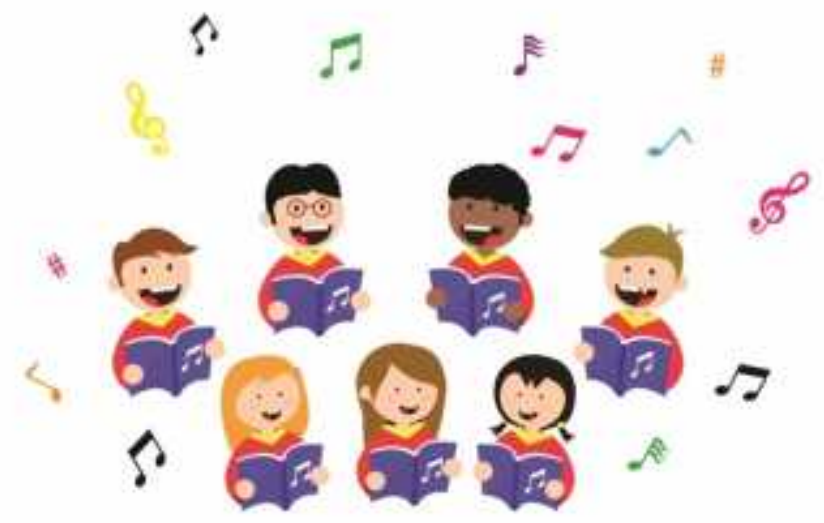

ISMANIAR

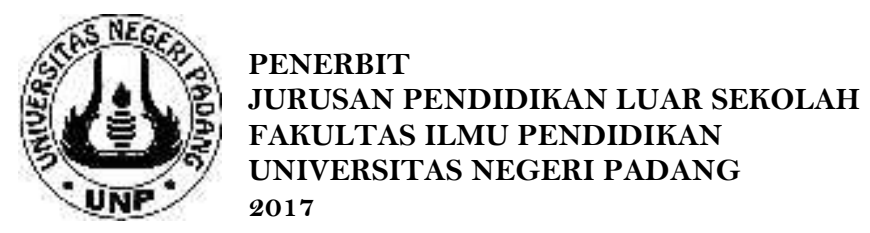


Sanksi Pelanggaran Pasal 72:

Undang-Undang Nomor 19 Tahun 2002

tentang Hak Cipta

1. Barangsiapa dengan sengaja dan tanpa hak melakukan perbuatan sebagaimana dimaksud dalam Pasal 2 ayat (1) atau Pasal 49 ayat (1) dan ayat (2) dipidana dengan pidana penjara masing-masing paling singkat 1 (satu) bulan dan/atau denda paling sedikit Rp1.000.000,00 (satu juta rupiah), atau pidana penjara paling lama 7 (tujuh) tahun dan/atau denda paling banyak Rp5.000.000.000,00 (lima miliar rupiah).

2. Barangsiapa dengan sengaja menyiarkan, memamerkan, mengedarkan, atau menjual kepada umum suatu Ciptaan atau barang hasil pelanggaran Hak Cipta atau Hak terkait sebagaimana dimaksud pada ayat (1) dipidana dengan pidana penjara paling lama 5 (lima) tahun dan/atau denda paling banyak Rp500.000.000,00 (lima ratus juta rupiah). 


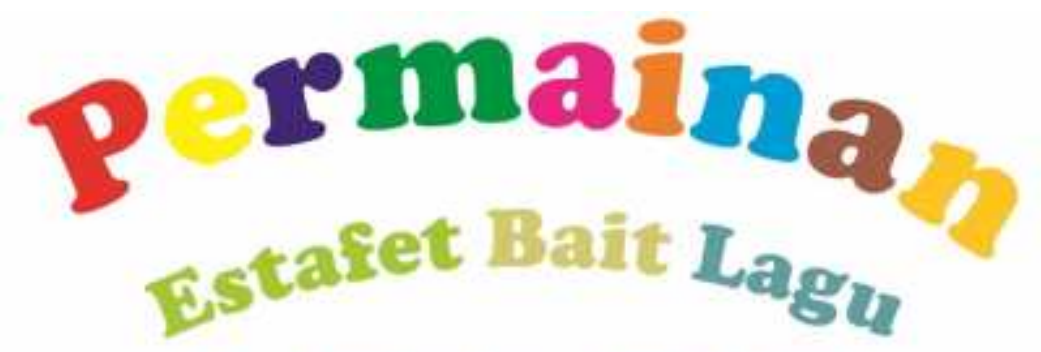

Model Pemusatan Perhatian sesuai Karakter dan Gaya Belajar Anak Usia Dini

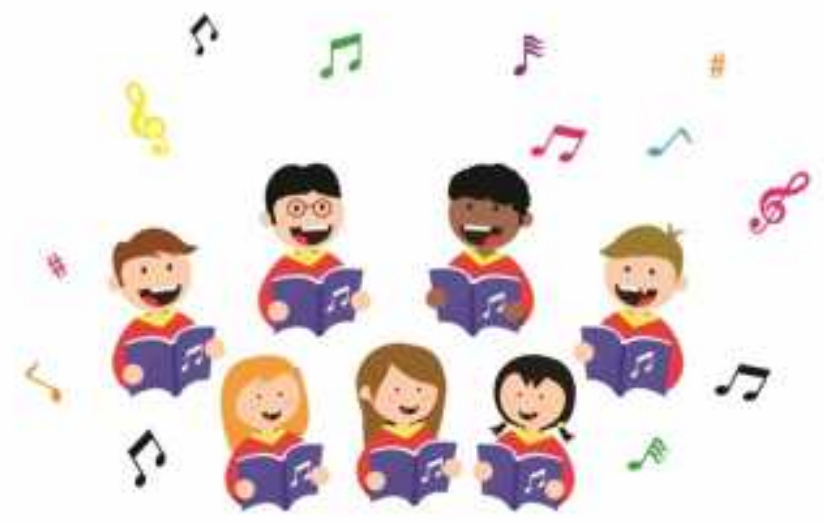

ISMANIAR

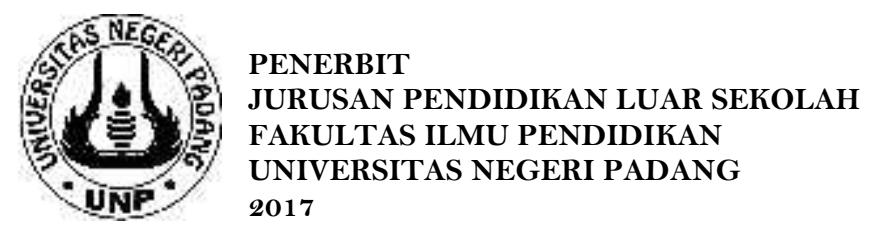




\section{Buku Panduan}

\section{PERMAINAN ESTAFET BAIT LAGU}

Model Pemusatan Perhatian sesuai Karakter dan Gaya belajar Anak Usia Dini

Penerbit Jurusan Pendidikan Luar Sekolah

Fakultas Ilmu Pendidikan Universitas Negeri Padang

Padang, Sumatera Barat

Indonesia

Penulis : Ismaniar

Copyright@2017

by Penerbit Jurusan Pendidikan Luar Sekolah

Fakultas Ilmu Pendidikan Universitas Negeri Padang

Padang, Sumatera Barat

Pertama kali diterbitkan dalam

Bahasa Indonesia

Oleh

Penerbit Jurusan Pendidikan Luar Sekolah

Fakultas Ilmu Pendidikan

Universitas Negeri Padang

Cetakan pertama: 2017

ISBN 978-602-60486-2-2

Hak cipta dilindungi undang-undang.

Dilarang memperbanyak sebagian atau seluruh

isi buku ini tanpa izin tertulis dari Penerbit. 


\section{KATA PENGANTAR}

Puji dan syukur penulis panjatkan kehadirat Allah SWT yang telah melimpahkan rahmad dan hidayah-Nya, sehingga penulis telah berhasil menyelesaikan penyusunan buku panduan "Permainan Estafet Bait Lagu" ini. Permainan ini merupakan salah satu cara kreatif dalam meningkatkan kemampuan pemusatan perhatian yang sesuai dengan karakter dan gaya belajar anak usia dini.

Buku panduan permainan ini merupakan salah satu produk dari penelitian dan pengembangan pada bidang pendidikan anak usia dini. Buku panduan ini dapat membantu guru dalam meningkatkan kemampuan pemusatan perhatian anak dengan cara yang menyenangkan.

Penulis menyadari dalam proses penyelesaian buku panduan ini banyak sekali dukungan dan bantuan yang datang dari berbagai pihak. Ucapan terima kasih dan penghargaan yang setinggi tingginya penulis sampaikan kepada berbagai pihak yang telah turut membantu penyusunan buku panduan ini.

Buku panduan ini diharapkan dapat menjadi referensi atau acuan bagi pendidik dalam meningkatkan kemampuan pemusatan perhatian anak melalui model permainan.

Jakarta, September 2016

Penulis

ISMANIAR 


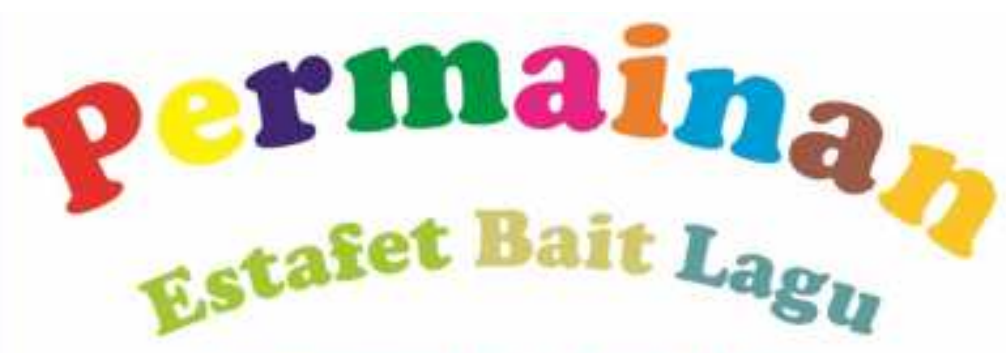

Model Pemusatan Perhatian sesuai Karakter dan Gaya Belajar Anak Usia Dini

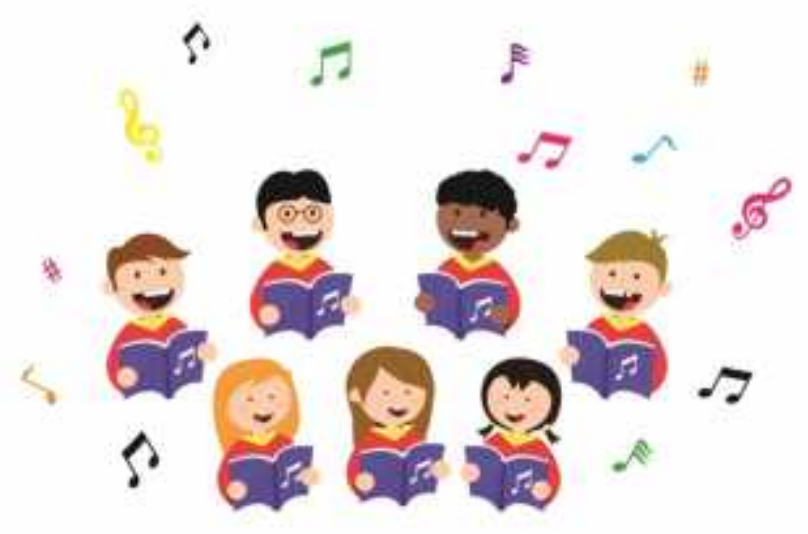




\section{DAFTAR ISI}

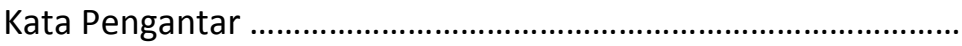

Daftar Isi

Bab I Pendahuluan ............................................................ 1

Latar Belakang ...................................................... 1

Tujuan ................................................................. 5

Bab II Konsep Model Permainan .......................................... 7

Pemusatan perhatian melalui model permainan 7

Aspek kemampuan pemusatan perhatian anak

usia dini .................................................................... 10

Indikator kemampuan pemusatan perhatian anak

usia dini ............................................................... 11

Alternatif lagu sesuai dengan tema ....................... 13

Media permainan Estafet Bait Lagu ....................... 15

Asesmen kemampuan pemusatan perhatian anak

usia dini ................................................................. 22

Bab III Pelaksanaan model permainan ................................. 23

Langkah-langkah pelaksanaan kegiatan ................ 23

Petunjuk permainan .............................................. 27

Contoh rencana kegiatan harian ........................... 29

Asesmen kemampuan pemusatan perhatian anak 37

Daftar Pustaka ........................................................................... 45 


\section{Latar Belakang}

embaga Pendidikan Anak Usia Dini (PAUD) adalah tempat atau wadah layanan yang ditujukan untuk mengembangkan berbagai aspek kecerdasan pada anak. Keberhasilan stimulasi yang diberikan di lembaga PAUD akan menjadi modal bagi anak ketika mereka mulai memasuki pendidikan dasar (SD). Di lembaga PAUD berbagai bentuk stimulasi dilakukan dengan menggunakan metode maupun materi yang beragam. Untuk dapat mengikuti stimulasi yang dilakukan serta berkembang sesuai harapan maka anak harus mampu memusatkan perhatian ketika mengikuti kegiatan.

Perhatian merupakan prerequisite atau persyaratan dalam melakukan tugas-tugas belajar. Mangel, dkk mengatakan; "Because attention is where learning begins, attracting and maintaining student attention are essential. Effective teachers plan their lessons so student attend to what 
is being taught and ignore irrelevant stimuli". ${ }^{1}$ Oleh sebab itu, salah satu yang perlu dituntaskan anak dalam masa perkembangannya adalah kemampuan dalam menentukan pilihan terhadap apa yang perlu diperhatikannya. Kemampuan ini membantu anak dalam memproses stimulasi atau rangsangan yang ditangkap oleh panca indra dengan cermat. Ketidakmampuan untuk menentukan pilihan dalam pemusatan perhatian akan menyebabkan anak tidak dapat memproses stimulasi dengan cermat dan tidak fokus/memindahkan perhatiannya sebelum ia dapat mengambil manfaat dari stimulus yang diperhatikannya.

Untuk mengatasi permasalahan masih banyaknya anak yang mengalami gangguan pemusatan perhatian, maka perlu dicarikan solusi kreatif sekaligus menyenangkan bagi anak untuk meningkatkan kemampuan pemusatan perhatian mereka. Sehingga situasi pembelajaran yang diharapkan dapat terwujud dan pada akhirnya tujuan pembelajaran dalam rangka mengembangkan berbagai aspek kecerdasan anak tercapai dengan maksimal.

Model permainan yang tepat menjadi salah satu penentu keberhasilan dalam kegiatan stimulasi perkembangan anak usia

\footnotetext{
${ }^{1}$ Paul Eggen, Don Kauchak. Educational Psychology, Windows on Classroom. New Jersey : United States of America. 2007. P211
} 
dini. Permainan sangat penting digunakan dalam kegiatan pengembangan anak usia dini, karena stimulasi yang dilakukan akan mudah diterima oleh anak melalui kegiatan bermain, termasuk dalam stimulasi peningkatan kemampuan pemusatan perhatian.

Mungkin banyak orang menganggap bahwa bermain itu adalah kegiatan yang sis-sia, namun David Whitebread ${ }^{2}$ seorang psikolog dari Cambridge University mengatakan; "Play is often perceived as immature behavior that doesn't achieve anything. But it's essential to their development. They need to learn to persevere, to control attention, to control emotions. Kids learn these things through playing". Bermain sering dianggap sebagai perilaku yang tidak mencapai apa-apa (tidak bermanfaat). Tapi bermain itu penting untuk perkembangan anak. Mereka perlu belajar untuk bertahan, untuk mengendalikan perhatian, mengendalikan emosi. Anak-anak belajar hal-hal ini melalui bermain.

Pendapat yang sama juga dikemukakan oleh Spencer dalam Musfiroh ${ }^{3}$ mengatakan bermain sangat penting bagi anak. Anak-anak harus bermain agar mereka dapat mencapai perkembangan yang optimal. Lebih lanjut Erikson ${ }^{4}$ juga

\footnotetext{
2 David Kohn, Let the Kids Learn Through Play, diakses dari http://www.nytimes.comopinion/sunday/let-the-kids-learn-through-play.html?_r=0 pada tanggal 17 Mei 2015)

${ }^{3}$ Musfiroh, Tadkiroatun, Cerdas Melalui Bermain., (Jakarta: Grasindo, 2008). hlm. 5.

${ }^{4}$ lbid.
} 
mengemukakan bahwa melalui bermain anak akan memperoleh kemampuan untuk menguasai tubuh mereka, benda-benda dan keterampilan sosial.

Bermain merupakan cara dan jalan anak berpikir dan menyelesaikan masalah. Sementara itu Mayke ${ }^{5}$ mengatakan bahwa berbagai manfaat bisa diperoleh melalui kegiatan bermain aktif, antara lain mengembangkan kemampuan anak untuk berdaya cipta (kreatif), melatih keterampilan motorik halus, melatih pemusatan perhatian, ketekunan dan daya tahan.

Aktivitas musik bisa digolongkan ke dalam jenis bermain aktif bila anak melakukan kegiatan musik, misalnya bernyanyi, memainkan alat musik tertentu atau melakukan gerakan atau tarian yang diiringi musik. Bernyanyi merupakan kegiatan yang paling banyak dilakukan karena tidak menuntut keahlian memainkan alat musik tertentu.

Menurut Bronson dalam Musfiroh ${ }^{6}$ jika pada usia 4 tahun anak data mencerna garis besar lagu, maka pada usia 5 tahun anak sudah mulai mengenal ritme dengan baik termasuk jinggel. Mereka dapat bernyanyi bersama dan mampu

\footnotetext{
${ }^{5}$ Mayke S. Tedjasaputra, Bermain, Mainan, dan Permainan, (Jakarta: Grasindo, 2001), hlm. 57.

${ }^{6}$ Musfiroh, op. cit, hlm. 84.
} 
mengikuti bit musik. Mereka dapat menikmati musik terekam dan menguasai lagu-lagu anak-anak.

Berdasarkan latar belakang tersebut, peneliti mengembangkan suatu model permainan pemusatan perhatian pada anak. Sesuai dengan disain penelitian yang dikembangkan, model permainan ini diberi nama permainan "Etafet Bait Lagu". Model permainan ini dirancang dengan memperhatikan karakteristik anak usia dini serta mempertimbangan gaya belajar anak yang beragam.

\section{Tujuan}

dapun tujuan buku panduan permainan ini disusun
adalah dalam rangka membantu guru memahami
model permainan pemusatan perhatian anak sehingga guru menguasai langkah-langkah pelaksanaan permainan. Buku panduan ini juga dilengkapi dengan konsep permainan, tujuan permainan, capaian perkembangan, indikator kemampuan pemusatan perhatian anak, alternatif lagu-lagu sesuai dengan tema, media permainan, petunjuk permainan, rencana kegiatan harian dan langkah-langkah pelaksanaan permainan pemusatan perhatian anak. Di harapkan dengan adanya buku ini guru dapat melatih 
Pendahuluan

kemampuan pemusatan perhatian anak dengan cara yang menyenangkan. 